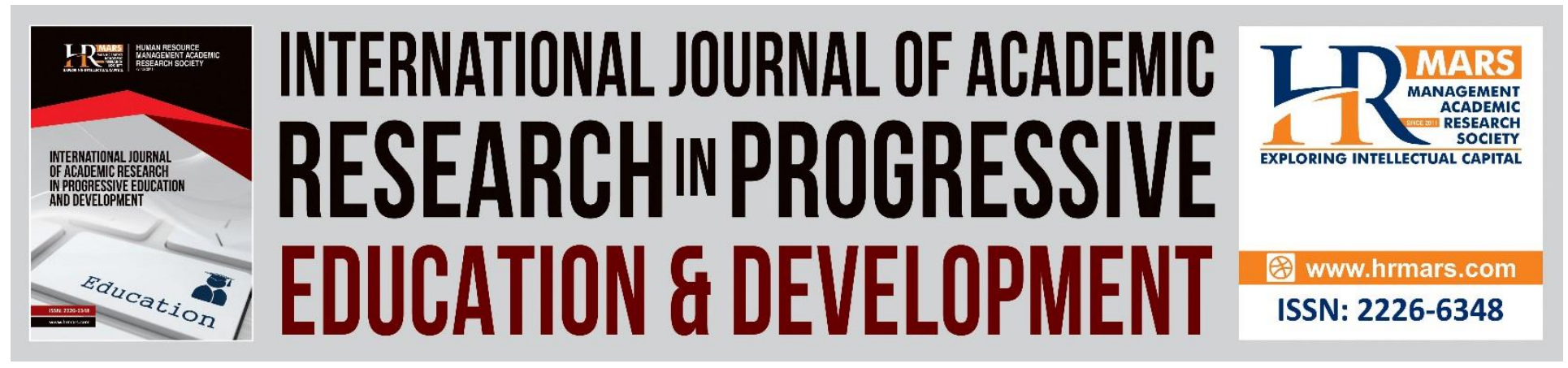

\title{
Effects of The IBE History Module on The Knowledge of Writing History Essays and Achievement among Form Six Students
}

Noor Shafinaz Mansor, MD. Nasir Masran

To Link this Article: http://dx.doi.org/10.6007/IJARPED/v10-i2/10209

DOI:10.6007/IJARPED/v10-i2/10209

Received: 07 April 2021, Revised: 10 May 2021, Accepted: 25 May 2021

Published Online: 19 June 2021

In-Text Citation: (Mansor \& Masran, 2021)

To Cite this Article: Mansor, N. S., \& Masran, M. N. (2021). Effects of The IBE History Module on The Knowledge of Writing History Essays and Achievement among Form Six Students. International Journal of Academic Research in Progressive Education and Development, 10(2), 715-726.

Copyright: (C) 2021 The Author(s)

Published by Human Resource Management Academic Research Society (www.hrmars.com)

This article is published under the Creative Commons Attribution (CC BY 4.0) license. Anyone may reproduce, distribute, translate and create derivative works of this article (for both commercial and non-commercial purposes), subject to full attribution to the original publication and authors. The full terms of this license may be seen at: http://creativecommons.org/licences/by/4.0/legalcode

Vol. $10(2)$ 2021, Pg. 715 - 726

http://hrmars.com/index.php/pages/detail/IJARPED

JOURNAL HOMEPAGE

Full Terms \& Conditions of access and use can be found at http://hrmars.com/index.php/pages/detail/publication-ethics 


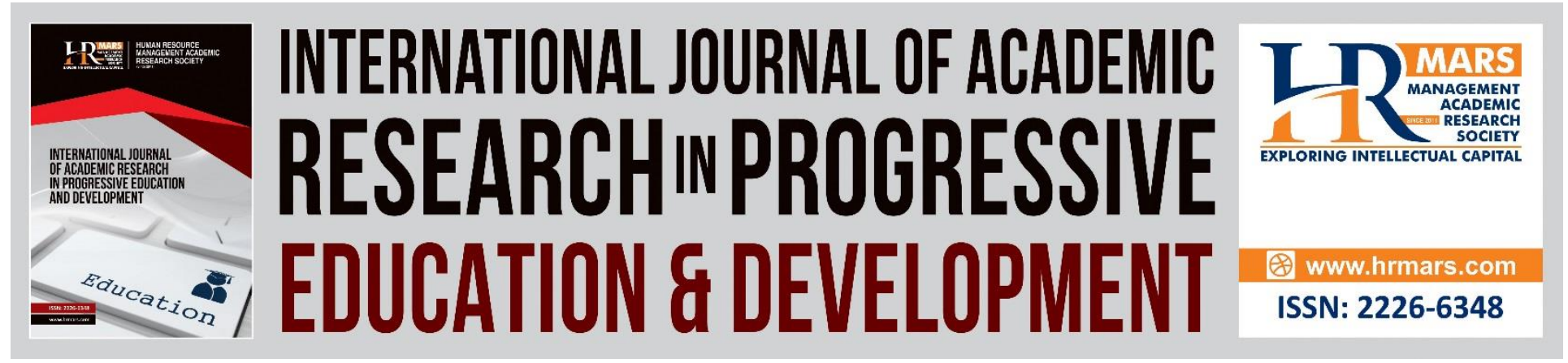

\title{
Effects of The IBE History Module on The Knowledge of Writing History Essays and Achievement among Form Six Students
}

\author{
Noor Shafinaz Mansor, MD. Nasir Masran \\ Faculty of Human Development, Sultan Idris University of Education, Tanjong Malim, Perak. \\ Malaysia
}

\begin{abstract}
The purpose of this study is to develop and evaluate the IBE History Module on the knowledge of writing essays and achievement among Form Six students. The development of this module is based on the Intro-Body Ending (IBE) method and the STPM Historical Coding Section (PTK). IBE is an essay outline site designed in the form of a numerical table that contains an introduction, content and conclusion. Students should write each section of the skeleton in accordance with the specifications required in the STPM History Scoring Section (PTK). The STPM Historical Scoring Section (PTK) is a grading method based on the level of efficiency with clear criteria. Students have been told in advance each step and what they can do. The ADDIE model, which includes the phases of needs analysis, design, development, implementation, and evaluation is at the heart of this study. The IBE History Module is a module built on the Needham Five-Phase Constructivism learning theory (Ricahrd, 1987). Modules are a set of teaching materials used to assist teachers in the PdP process in schools. Therefore, a quantitative study to be conducted by the researcher aims to test the effects of the IBE History Module that the researcher has developed through the quasi-experimental method. The study sample consisted of 120 Form Six students randomly selected. The students will be divided into two research groups, the experimental group and the control group. Whereas, the research instrument is a test of history essay achievement and student achievement level. The scores obtained by the students will be extracted and analyzed using System Packages for Social Sciences SPSS version 20 through independent sample t-test for pre- and post-test.

Keywords: IBE History Module, Intro-Body Ending (IBE) Method, STPM Historical Scoring Section (PTK), ADDIE Model, Needham Five-Phase Constructivism learning theory (Ricahrd, 1987), QuasiExperimental
\end{abstract}




\section{Introduction}

In an educational institution, the teaching and learning process (PdP) can be seen as an important force or impetus for shaping human capital. Dynamic and systematic management of PdP enables the development of scientific culture, new knowledge, creative and innovative ideas, more sustainable human development and information dissemination (Jantan, 2016; Faizah, 2017). Modules are instructional materials that have been divided into specific sub-topics and the order in which each subtopic has relevance or continuity to each other. Modules in the form of course materials (subjects, exercises etc.) are implemented individually to achieve a skill (Ismail, 2018). The teaching module is an innovation or printed material that contains suggested activities, methods, presentation styles, procedures and guides to convey the content to the students and also comes with a lesson plan to achieve the learning objectives set within a few hours (Hafizah, 2017). Based on the theory of constructivism and interactional learning, this module is designed to help teachers apply theory in the form of teaching practices as a basis for producing teaching and learning activities that include strategies, methods and techniques for teachers to use in a student-centered classroom environment (Ali, 2015). Modular teaching and learning provides the opportunity for users to learn self-directed, self-directed and self-directed.

\section{Problem Statement}

Teacher readiness and teaching in the school are the cornerstone of the success of the student and the school. However, teacher readiness and Form Six teaching are issues that are rarely discussed or explored. Looking at the current state of the Sixth or Pre-university school system in the country, teachers who teach Sixth Form are seen as unable to escape the problems of teaching especially in terms of teacher readiness and implementation (Kasmani, 2013). In addition, teachers who teach Form Six often have problems in terms of knowledge preparation before beginning teaching. They need to be better prepared because the subjects taught have a broader scope and scope (Kasmani, 2013). According to Ishak (2017), the issue of pedagogy involving teaching and teaching approaches is still a major issue that needs to be addressed among school teachers who teach Form Six students. However, there are problems that Form Six students often face in History subjects, namely History writing skills. The satisfaction level of teaching students to effectively decipher historical facts has not reached their maximum potential (Ban, 2018). Therefore, a History Semester 1 essay writing module will be developed to study the effects of using the Intro-Body Ending History Module (IBE) to improve knowledge of writing skills History essay and level of achievement among Form Six students.

\section{Research Objective}

i. Identify the content design of the IBE History Module on the knowledge of writing skills and achievement in Form Six students.

ii. Design and develop the IBE History Module on the knowledge of writing skills and achievement in Form Six students.

iii. Evaluate the impact of the IBE History Module on Form Six student writing skills.

iv. Assessing the impact of the IBE History Module on the achievement of Form Six students.

v. Review teachers' opinions on the effects of the IBE History Module. 


\section{Research Questions}

In this study there are several questions to look at regarding the impact of the IBE History Module on the knowledge of writing essays history and achievement among Form Six students. This study was conducted to answer the following research questions:

i. How to verify contents of IBE History Module content.

ii. How to design and develop IBE History Modules for knowledge of writing skills and achievement in Form Six students?

iii. How does the IBE History Module affect essay writing skills and Form Six student achievement.

iv. What is the teacher's opinion on the effects of the IBE History Module.

\section{Research Conceptual Framework}

This study was conducted to study the impact of the IBE History Module on the knowledge of History writing skills and achievement among Form Six students. Therefore, the final step in the construction of the IBE History Module is to look at the content of the module which will affect the students' writing history through the Intro-Body Ending (IBE) and STPM History Scoring Section (PTK) methodology, thus affecting the student achievement level in the STPM History Trial Exam Semester 1. 
INTERNATIONAL JOURNAL OF ACADEMIC RESEARCH IN PROGRESSIVE EDUCATION AND DEVELOPMENT

Vol. 10, No. 2, 2021, E-ISSN: 2226-6348 @ 2021 HRMARS

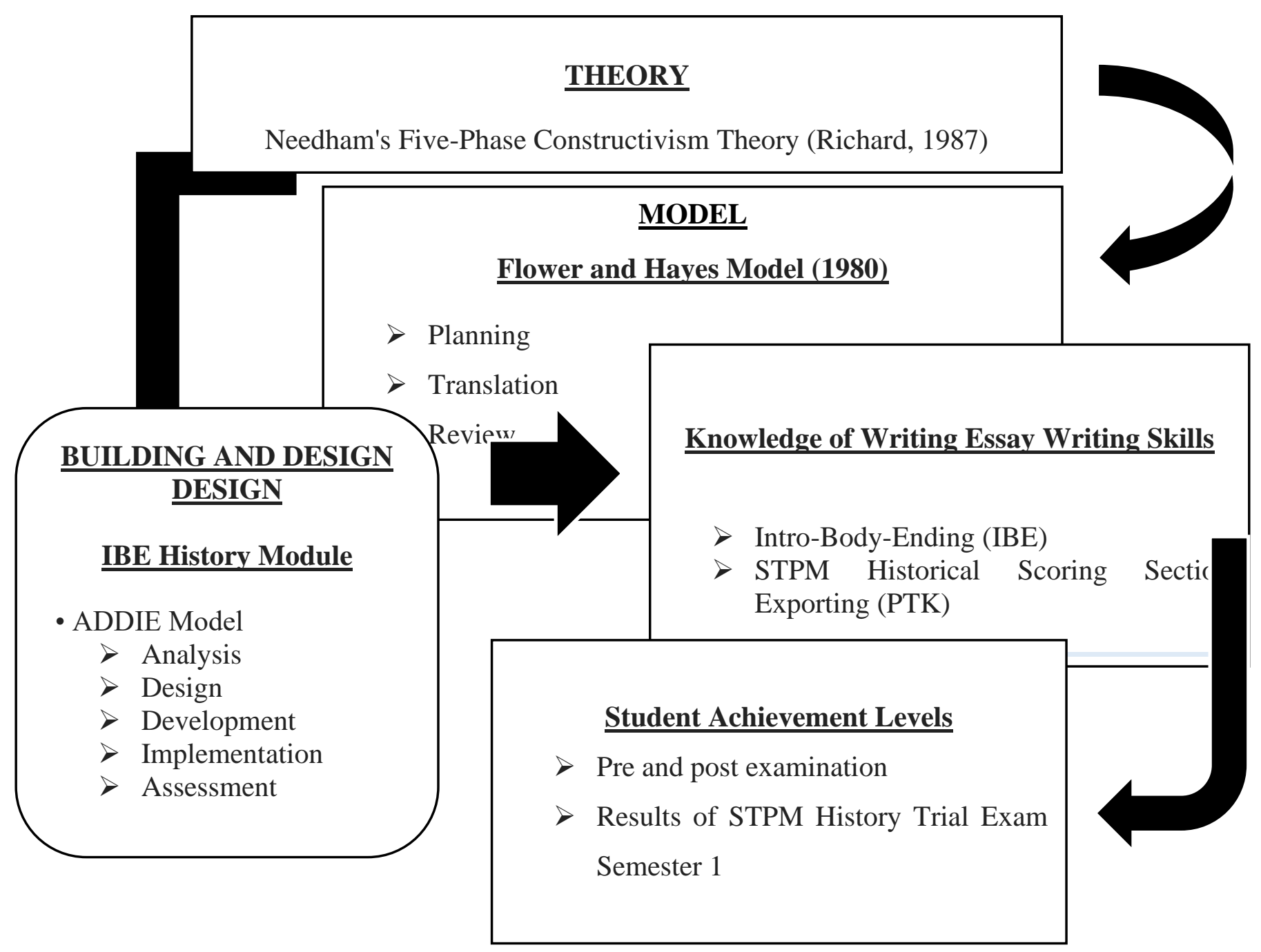

Figure 1 : Theory of Study 
INTERNATIONAL JOURNAL OF ACADEMIC RESEARCH IN PROGRESSIVE EDUCATION AND

DEVELOPMENT

Vol. 10, No. 2, 2021, E-ISSN: 2226-6348 @ 2021 HRMARS

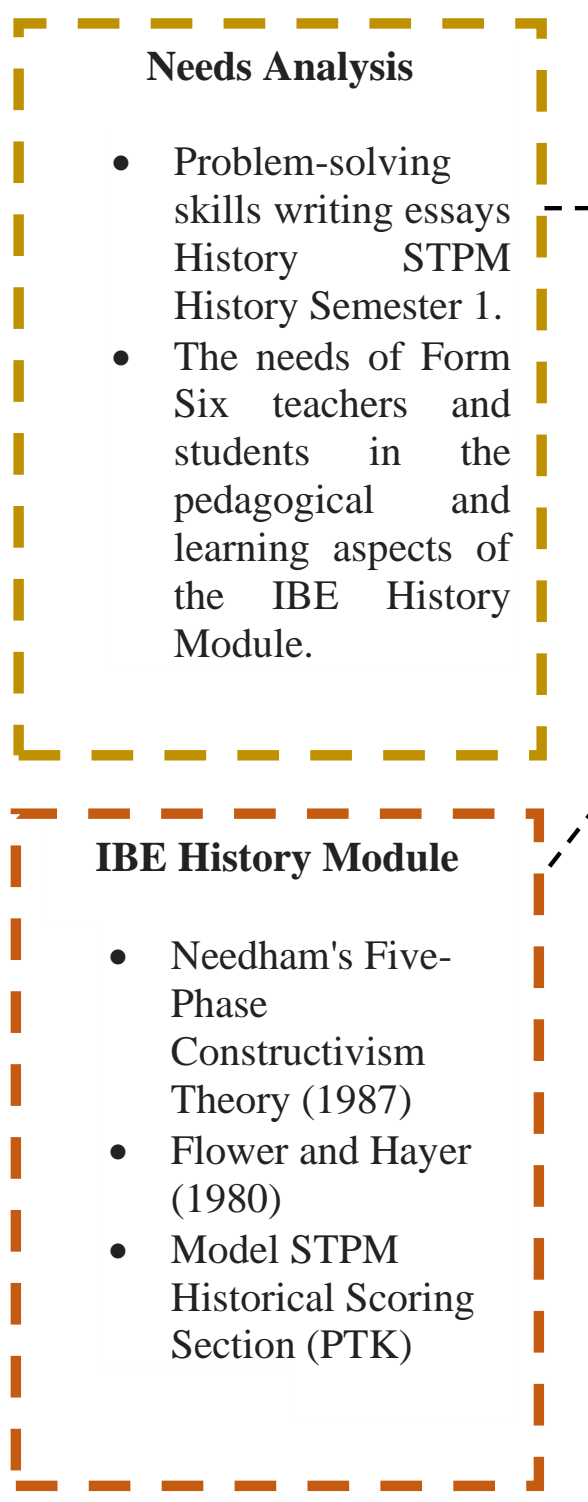

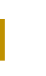

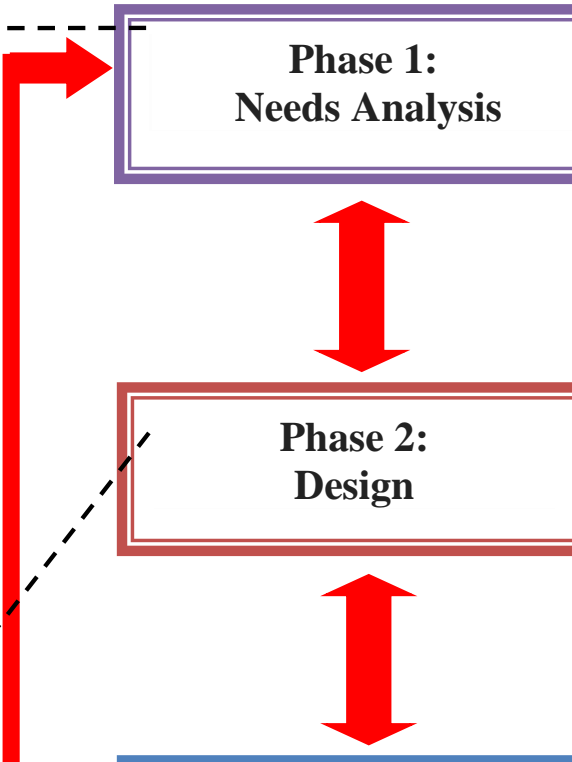

Phase 3:

Development

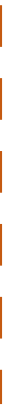

Figure 2 : ADDIE Model Study Design 


\section{Importance of Study}

The importance of a study must be significant as it has great implications in improving or finding a solution to a problem for the study being conducted (Hassan, 2015). The development of the IBE History Module helps teachers provide a fun learning environment while also reducing teacher teaching tasks. Learning fun is the expectation of teachers in the learning process of students (Chung, 2017). Building the IBE History Module on the skills of writing History essays and student achievement can help History teachers plan effective teaching and learning activities for students in the classroom. The teacher will identify the existing knowledge of the student and design his / her teaching method based on the nature of the knowledge (Hasan, 2019). It is an improvement of educational practice especially in improving the efficiency and effectiveness of teacher teaching and in turn enhancing the teaching of professionalism. The development of modules based on Form Six History Syllabus can overcome teachers' difficulty in pursuing syllabus due to time constraints and other causes. Teachers can save time in planning lesson plans (Kasmani, 2013). The findings of this study hope to help all teachers not only history teachers to be mentally and emotionally prepared, to make continuous improvements in teaching and learning and to always find effective teaching strategies for teaching and learning to be practiced was planned.

\section{Subject of Study}

The research was focused on the use of learning theory, Five-Phase Constructivism Theory of Needhan (1987) to enhance students' understanding of a History concept and to encourage students to be actively involved in the classroom. The model consists of five phases namely orientation phase, idea trigger phase, idea restructuring phase, idea application phase and reflection phase (Dayana, 2012). This study uses qualitative and quantitative approaches. A quantitative approach with a quasi-experimental design was used in this study. The subject selection of the study was conducted by cluster sampling involving 120 Form Six students at three secondary schools in Selama and Taiping, Perak. The study subjects consisted of 20 experimental group students and 20 control group students. Three research instruments were used: a set of pre and post test questions and a questionnaire form. The questions for the survey form were based on previous studies and were modified according to the needs of the study. The qualitative method used interviews with three Form Six history teachers and 15 Form Six students as well as observations through student learning sessions in the classroom. In the construction of the IBE History Module, the ADDIE model was selected because it is easier to implement and implement in the development of learning programs (Zulkifli, 2017).

\section{Methodology}

This study is an experimental study design. Experimental studies are quantitative designs to test the hypothesis of significant comparisons or differences between the 'treatment' group (the experimental group) and the control group, or between two independent variables (experimental group) and the dependent variable (control group). The purpose of the experimental study was to test or test the effects of any effect, or to establish causal relationships and both causal studies involved group comparisons (Darusalam, 2018). Observation is regulated so that factors other than the aspects of treatment that may influence can be eliminated. The 
experimental design used in this study was to investigate the causal relationship by exposing one or more experimental groups to one or more treatments and comparing them to one or more control groups that did not receive any treatment (Original, 2014). This study used pre-test design and testing on treatment and control groups. The purpose of this study is to test the effect of the dependent variable on the dependent knowledge of the history writing skills. The independent variables in this study were the treatment group (Y1) and the control group (Y2). Treatment and intervention using the IBE History Module will only be performed on the treatment group (Y1). Study 01 and Position 02 were conducted to measure the dependent variables, which were the students' writing skills History history and student achievement in the STPM History Trial Exam Semester 1.

The experimental study design used in this study was to investigate the cause-effect relationship by exposing one or more experimental groups to one or more treatments and comparing them to one or more control groups that did not receive any treatment (Original, 2014). This study used preliminary design and evaluation of treatment and control groups. The factors involved in the design of this study are as shown in the following table.

Design of Experimental Studies on Knowledge Writing Writing Essays and Student Achievements Using the IBE History Module

\begin{tabular}{llll} 
Group Y1 & 01 & $x$ & 02 \\
Group Y2 & 01 & - & 02 \\
\hline
\end{tabular}

Guidance :

$\mathrm{Y} 1=$ treatment group

$\mathrm{Y} 2$ = control group

$01=$ pre-test

02 = test post

$\mathrm{X}=$ treatment $/$ intervention

Based on the table above, the purpose of this study is to test the effect of the independent variable on the dependent variable on History writing skills. The independent variables in this study were the treatment group (Y1) and the control group (Y2). Treatment and intervention using the IBE History Module will only be performed on the treatment group (Y1). Study 01 and Position 02 were conducted to measure the dependent variables, which were the students' writing skills History and student achievement in the STPM History Trial Exam Semester 1.

Pilot testing is a mechanism for identifying problems that may arise during the course of an actual study. Pilot testing should be done to detect early problems and to immediately address any weaknesses identified in a study (Darusalam, 2018). This pilot study aims to look at the suitability of the module in terms of content, timeliness of response and clarity of direction. According to 
Ghafar (2003), a pilot study was conducted with the aim of determining the validity and reliability of the instrument. Pilot studies do not need to be carried out if the instrument has a certainty of objective, validity, reliability and usefulness. This is rare because researchers need to be aware of sample characteristics that are quite different from previous studies. Pilot studies are also used to test the best methods for instrumentation, sample identification and the suitability of analytical methods. In this study, an important instrument for pilot studies was the questionnaire. A pilot study was conducted to determine the validity and reliability of the questionnaire based on phase-based goals.

After obtaining information through a pilot study, the researchers modified, refined and updated the items in the questionnaire. A University history expert reviewed the questionnaire that was refined before the actual study was conducted. In the actual study of need analysis, a questionnaire was given to 40 Form Six students from a school through a History teacher. In addition, a semi-structured interview with four of four that taught the Form Six History subject was conducted. The data collected from the questionnaire with the students were analyzed through SPSS while the findings from the interviews with the teachers were analyzed narrative

The ADDIE model is used to analyze problem-solving skills in writing the History of STPM Semester 1 History course and the needs of Sixth-grade teachers and students from the pedagogical and learning aspects of the IBE History Module. The ADDIE (Analysis, Design, Development, Implementation, Evalution) model has been selected for use as an instructional design design strategy. The ADDIE model is also a general model that is widely used in any program because of its easy-to-understand nature (Goh, 2009; Lai, 2018). In this study, the needs analysis was conducted for Form Six students. The purpose is to obtain information on the problem of learning skills of writing and the needs of Form Six students from the pedagogical and learning aspects of the IBE History Module. In addition, the needs analysis was also carried out on Form Six History teachers. Information gathered from Sixth History teachers is related to teachers' perceptions of the importance of teaching and learning essay writing as well as essay writing teaching practices for Form Six students and the problems encountered by teachers during the essay writing process.

Population is a group of individuals with the same criteria and characteristics as the purpose of the study conducted while the sample is a subgroup of the target population that the researcher intends to study in order to generalize the study population (Creswell 2008; Amalina, 2018). The population in this study consisted of Form Six students and Form Six history teachers in secondary schools in Selama and Taiping, Perak.

Selected sampling is a type of purposive sampling. It aims to obtain a sample of studies that have a low proficiency in History writing skills. Next, the sample distribution for treatment group and control group was performed using pair random sampling. The treatment group samples were treated with IBE History Module while the control group were not given any treatment. The sampling took only 40 students and two History teachers as research respondents to collect data through the observation that students and teachers used the IBE History Module during the 
teaching and learning (PdP) process to answer the third objective. A total of 120 students were selected as respondents to answer the fourth objective through the distributed questionnaire form. Meanwhile, six History teachers will be interviewed to collect data through interview results to answer the fifth objective.

The instrument used in this study was a set of questionnaires distributed to respondents for feedback. The questionnaire was obtained by the researcher based on the reference to the previous research questionnaire. The selection of questionnaires as instruments is based on its easy-to-manage features, saving time, energy and cost especially during the data analysis process (Amalina, 2017). The questionnaire consists of two sections, Part A and B. Part A covers the background of respondents and Part B deals with knowledge of essay writing skills, Form Six student achievement in the STPM History Trial Exam Semester 1 and teacher's opinion on the impact of using the History Module IBE in ABM teachers in the PdP process in the classroom. For each construct, a total of nine items (knowledge aspects), ten items (implementation skills aspects) and ten items (teacher's opinion aspects) were used to obtain respondents' feedback on the use of the IBE History Module.

This study uses qualitative and quantitative approaches. The quantitative method by testing is the pre test (traditional method) which is the control group and the post test (using the IBE History Module) which is the experimental group. The survey form was used as a research instrument. The questions for the survey form were based on previous studies and were modified according to the needs of the study. While the qualitative method uses the interview method with three History teachers and observations, through the student learning sessions in the classroom. The design of the teaching system is to use the ADDIE Model. In the construction of the IBE History Module, the ADDIE model was chosen because it is easier to implement and implement in the development of learning programs (Zulkifli, et al., 2017). Therefore, the findings of the study are valid only for the schools studied and cannot be generalized in all schools nationwide. The accuracy of the study also depends on the sincerity and openness of the students when answering pre and post test questions.

The questionnaire was used in the process of data collection in this study. This allows the respondents to complete the questionnaire at the convenience of the respondent (Hussein, 2014). The questionnaire was used to collect data related to the content design of the IBE History Module, develop the IBE History Module, the effects of the IBE History Module and to examine teachers' views on the impact of the IBE History Module on knowledge of writing skills and achievement of Form Six students

Observations are made to look at all activities, events or situations directly, or when necessary perspectives or when informants are unable or unwilling to discuss the topic being studied (Darussalam, 2018). Mohamad (2000) in Darussalam (2018) explains that observations are being made to gather 'non verbal' data to examine real-life situations or events, as well as to critically consider informal behavior. Observations are made in the classroom during the PdP session using the IBE History Module. All practices and behaviors of teachers and students are recorded or recorded. 
Vol. 10, No. 2, 2021, E-ISSN: 2226-6348 @ 2021 HRMARS

Partially structured interviews were among the instruments used in this study. Partially structured interviews were used in the needs analysis phase, design phase, development phase, and outcome evaluation phase (Lai, 2017). In the next phase of the analysis, face-to-face interviews with expert panel were conducted to obtain data to develop the essay writing module. A face-to-face interview with the teacher evaluation panel was also conducted before the module was used by the Form Six students. The aim is to study the strengths and shortcomings of the module. At the summative assessment stage, a group interview with the respondents was conducted to evaluate the usefulness of the developed module.

In the study of the effects of the IBE History Module for Form Six students, all data obtained from the questionnaire, namely, pre-design phase, pre-development phase, needs analysis phase, design phase, development phase, and evaluation phase were analyzed using " Statistical Package for the Social Science '(SPSS). Whereas data from interviews and documents were analyzed narrative. The research report is based on all the qualitative and quantitative data that has been collected and analyzed.

Formative evaluation was performed in this study. The generated modules were evaluated by the teacher evaluation panel. They are four History teachers who teach Form Six students. A set of semi-structured interview questions was developed and reviewed by a University historian. Researchers have interviewed the teachers for feedback, suggestions, and feedback on the strengths and shortcomings of the essay writing module. Researchers have analyzed the data collected through interviews. Module repair work is carried out.

A total of 40 Form Six students selected as respondents to use the essay writing module were asked to answer a questionnaire related to the level of behavior assessment before the module was implemented. The collected data were analyzed with SPSS. In addition, a pre-written test was conducted on the respondents. This pre-test is an instrument for level 2, which is learning assessment. Respondents were tested on essay writing skills. The purpose is to review the students' writing levels before the module is used by the selected respondents. The instrument used is the STPM Semester History Scoring Scheme 1. The students' answers to the pre-test were reviewed by a Grade Six teacher.

In addition to getting information from Sixth Grade teachers and Sixth grade students in the needs analysis phase, feedback, opinions and opinions from experts in related fields are also needed in this study. Thus, the three-stage Delphi technique was used to obtain information from the panel of experts. Individually structured interviews were conducted with experts for feedback and consensus on the development of IBE History Modules for Form Six students.

\section{Conclusion}

Building the IBE History Module on Writing and History Writing achievement among Sixth Grade students using the Intro-Body Ending (IBE) and STPM HistoricalScoring Section (PTK) method is seen as one of the teaching aids for the teaching process and learning. The key to the development of this module is to ensure that students gain knowledge of the systematic and 
Vol. 10, No. 2, 2021, E-ISSN: 2226-6348 @ 2021 HRMARS

well-organized history of writing skills while improving student achievement in writing the History essay.

\section{References}

Ahmad, A. (2013). Kesan Intervensi Psiko-Pendidikan Terhadap Tingkahlaku Murid Sekolah Menengah Oleh Guru Bimbingan dan Kaunseling. Tesis Phd Yang Tidak Diterbitkan: UM.

Ali, A. (2016). Modul Pengajaran Dan Pembelajaran Untuk Meningkatkan Keprofesionalan Guru Prasekolah Melaksanakan Kurikulum Berpusatkan Murid Dan Berasaskan Standard. Selangor: UKM.

Amalina, N. Z. I. (2017). Pengetahuan, Kemahiran Pelaksanaan Dan Sikap Guru Terhadap Pembelajaran Berasaskan Masalah (Pbm) Dalam Mata Pelajaran Sains Knowledge, Implementation Skills and Teachers' Attitude Towards.

Ban, J. (2018). Memantapkan kemahiran menulis esei sejarah stpm menggunakan "sarang" dalam kalangan pelajar tingkatan 6 semester 1 um., jurnal pendidikan tingkatan enam. (2018). Jilid 2: kementerian pendidikan malaysia.

Chung, L. L. (2017). Pembangunan Dan Penilaian Modul Penulisan Karangan Bahasa Melayu Tingkatan Empat . Kuala Lumpur: UM.

Dayana, N. (2012). Aplikasi Teori Konstruktivisme dan Model 5 Fasa Needham dalam Pembelajaran Perisian ChemMol, https://people.utm.my/noordayana/files/2012/10/paper-pappp-full-dr-dayana.pdf

Ghazali, S. H. (2018). Metodologi Penyelidikan Dalam Pendidikan, Amalan dan Analisis Kajian. Kuala Lumpur : UM.

Hassan, Y. C. (2015). Pengetahuan, Sikap dan Kesedaran Pensyarah Dalam Pengamalan Penyelidikan di Politeknik Premier, Serdang: UPM.

Ja'apar, F. (2017) bahan bantu mengajar (bbm) dalam pengajaran dan Pembelajaran ( $p \& p)$ di sekolah menengah kebangsaan (smk) daerah pontian. Johor: uthm.

Kasmani, N. A. (2013). Kesediaan guru dan pelaksanaan pengajaran tingkatan Enam di sekolah menengah daerah muar. Johor: utm.

Masni, N. M. (2017). Pembinaan Modul Pembelajaran Teradun Nutrisi Di Hujung Jari Dan Kesannya Terhadap Pencapaian Pelajar.Perak : UPSI

Rahmah, N. (2017). Model Hybrid Addie Untuk Rekabentuk Aplikasi Gamifikasi Pembelajar Matematik Bagi Pelajar Pemulihan Di Malaysia, International Conference On Special Education In Southeast Asia Region 7th Series 2017417. 